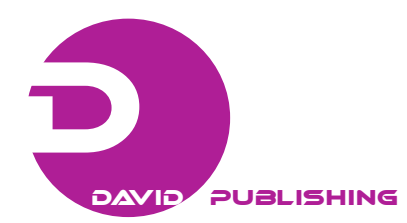

\title{
Education and Democracy
}

\author{
Salome Pataridzea, Tinatin Sakhelashvilib, Tinatin Sabaurib
}

\begin{abstract}
Over the past decades, there were questions often asked: What is education? What is it purpose in the world whether it helps an individual or not to understand himself and connect his views with existing beliefs and critical thinking about education to deal with daily practical challenges enable in a new way. The founder of instrumentalism philosophical school, John Dewey remarks that knowledge is practical instrument that purpose must be to solve all problems that a person encounters during his/her lifetime. According to instrumentalism theoretical concepts, theories are instruments by means of that relationship with surrounding world is established (communication becomes possible). Representatives of traditional epistemology make distinct difference between "world" and "mind". In accordance with Dewey's genetic epistemology mind, constitutes the result of living being-environment relationship as the universe is defined by our mind and the development of a human's knowledge is adaptive response to the environment.
\end{abstract}

\section{Keywords}

Education, democracy, teaching

Children spend too much time in schools' little community that makes big influence on their development. School is a social system, which children obey or oppose. However, the system should provide the pupil as an individual with integration in the society that will become a certain precondition of developing their adaptive skills. Nil Postman describes the school as the space, where pupils should study how to make their private interests subject to the group interest.

Dewey was concerned that the lives of students were so often systematically sacrificed to some future good that education was thought to have a purpose far beyond the present interests and purposes of students. He does not deny that particular aims are appropriate within education. We, teachers and students are trying to accomplish something, but our aims are not fixed. As long as a particular aim functions adequately to guide our activity, we retain it, but when this aim fails and is not our guide, we leave it and choose another, more suitable aim, this is a clear example for meaning, that dewey was interested in an analysis of education as a social phenomenon. He claims that not only teachers must have aims for their chosen activities, students must be involved in their own learning. For example, in the whole language approach, we do not try to prepare children for future language activities by teaching them bits of sound, spelling, and grammar. Instead, we encourage them to follow their own purposes in communication. Also, they are helped to write their own stories and read them to their classmates. With this methods, students begin to “think". Dewey's model of thinking is still influncial today (Noddings 2007: 26-30). Following Dewey:

allia State University, Georgia

bTbilisi State University, Georgia

\section{Correspondent Author:}

Tinatin Sakhelashvili, Tbilisi Tsintsadze \#26

E-mail: tikosaxe@mail.ru 
(1) Thinking begins with concern that something is unsolved;

(2) Exploring a hypothesis that must be tasted;

(3) The thinker makes up a plan, by which the hypothesis can be tasted;

(4) The thinker considers alternatives;

(5) How better methods might be used in future situation and a thinker makes a generalization.

\section{METODOLOGY}

\section{Democracy and Instrumentalism}

Similarly, learning to participate in democratic life involves living democratically-students working together on common problems, set the regulation by which their classrooms will be ruled, tasting and evaluating ideas for the improvement of classroom life, learning and participating in the construction of objectives for their own learning. Neither of us begins life with common values, we construct them. This does not mean that every culture should not transmit own values, but values must be discussed and tasted. Connection between education and democracy is very important and school cannot prepare students for democratic life by simply giving them information. Instead, it prepares students for democratic life by involving them in forms of democratic living suitable for their age. For Dewey, democracy is not a system of government in which everyone votes and the majority prevails. Rather, a democracy is characterized as followers: “There are many interests consciously communicated and shared and there are varied and free points of contact with other modes of association” (Noddings 2007: 37). Also, translating this thinking to the democratic classroom, we support the idea that schools should be organized democratically, because they are micro-socies in which children learn trough practice how to promote their own growth, that of other, and that of the whole society.
When we are talking about democracy, we mean a governance system, in which control over policy choices is chiefly vested in elected officials chosen through fair and frequent election in which virtually all adult citizens may participate. The practice of democracy presumes a degree of civility, shared knowledge, communicate face-to-face.

In America, the European model of education was acknowledged and for supporting this opinion, they set the following arguments:

(1) We think that European education system is the best model, because a poor man's son has chance to became rich by hard work and good knowledge. He can be famous and successful in his job. That is why we are trying to teach our children democratic values;

(2) Americans want schools to help individuals as well as to strengthen the collectivity. They believe that democracy is the best form of government. Schools must enhance students;

(3) At various points in American history, especially the past decade, some Americans have also demanded that schools fulfill a third goal-responding to the claims of particular groups. All the members of group should have the same chance to reach success. In this case, we mean racial, ethnic, religious, sexual, and other groups. That is why pupils must know communicate skills, basic literacy and numeracy, they should understand rules of law and politics. Teachers should teach them other tolerance, multicultural curriculum. After that, children will understand other peoples' history and culture, and know it as well as the own (Parker and Merryfield 2002: 6-13).

\section{Problems of Democratic Education and Discussion in Georgia}

Nowadays of the now called "classic" concept of socialisation is formulated that socialization is to be understood as the process of formation.

A fundamental part in school development process 
is the democratic pedagogy. How is the school's main problem-the social learning/cooperative study (service learning) should be solved? To what extent the participation of the pupils is promoted in school life (student initiatives, arbiters, class council, service learning)?

Georgian education system is the foundational document of the National Education Goals, where we read: "General education system in Georgia aims at creating convenient for developing an independent person with national and universal values".

The problem in Georgian reality is that implementation of all these in practice is difficult, because the state has so far been focused on the present, and have not realized the fact that the future is based on current education system.

Currently, the existing principle in our education system is similar to Western education standards, however, it is important that content aspects should be regulated (such as teachers' qualifications, pupils' independence, etc.).

It should be emphasized that in recent years, major changes can be observed in Georgia, the schools toward the socialization of students. Each school has a student council, school boards, student governments on which teachers and parents of students can also participate. In some schools, appeared students parliaments, students mediation groups, debate clubs, so that students can express their democratic initiatives, opinions, and desires.

In schools, psychologists and special educators were invited to provide the students with various learning difficulties and disabilities, the opportunity to learn with other healthy students in the classes. In the schools, there are the so-called resource rooms where individual study is conducted for the students who are enrolled in an inclusive program.

About the above topics, the authors compare the schools of developed countries and developing countries. As a first example, they observed the school system in Germany, they reviewed the basic principles of a democratic pedagogy, they talked with democracy educators, headmasters, experts, and students. In 2006 in Germany, democracy educators were trained and then since the basic principles of democratic education have been implemented in schools. Content areas of democracy pedagogical competencies are:

(1) Promoting self-efficacy: Self-efficacy refers to confidence in the personal skills to cope with problems on their own;

(2) Human rights and cultural difference: Human rights as a normative basis and for dealing with discrimination, racism, and social inequality. The focus of work is on this: Presenting educational strategies to human rights education and promoting intercultural school development;

(3) Conflict management/School development: Promoting conflict resolution skills is in the context of school development of a central democracy-pedagogical competence. You must be developed for both teachers and students. This includes: violence prevention and conflict management;

(4) Civic education: Civic education supports the design of experiential learning situations in democratic speech and fosters a willingness to take on responsibility;

(5) Values and moral education: Democratic education is especially valuable education. The aim is to develop the ability to take responsibility;

(6) Training civilcourage: Courage is a fundamental social competence. It is necessary to know when and how to intervene. Therefore, courage must be cultivated in educational processes and practiced in experience;

(7) Project didactics: The project wins for the development of a democratic school culture based on the new curricula that increasingly important. Main attention is paid to: The project method and the project in the school practice;

(8) Understanding intense;

(9) Understanding intense learn. 


\section{CONCLUSIONS}

Despite the fact that Georgia's educational system is being changed for the better way, we still have problems in this direction.

According to the statistical data:

Teachers (primary), 39.2\% think that the English language affects to the Georgian language; $52.9 \%$ of teachers think that every citizen of Georgia who did not know Georgian, must be deprived of citizenship; $74.9 \%$ of teachers think that a different sexual orientation is a threat to the public; $83.8 \%$ of teachers think that the non-traditional religions (sects) pose a threat to Georgia's statehood.

These data show that there is still much to be done if we want to be a part of civil world.

Based on this study, we can conclude that the problem of formation of a critical citizen in national education system still remains, as the educational practice in most cases is wrong. The students at school cannot make a choice. They cannot analyze learning objectives, moreover, others make decisions instead of pupils and as a result, the learning process becomes tiring and unpleasant.

Georgia, as the developing country, where democratic values are just being established, should take into consideration successful models of education system in developed countries, which the authors have discussed above on the examples of the USA and Germany. In Georgia, it is essential to establish democratic methods of education. As for centuries, traditional education model was developed and individualism was limited. The students had to adjust to existing education system and not on the contrary that creates global problems in the country.

In conclusion, it can be said that the state must invest great resources and energy in a successful education system, as a democratic society is based on successful and strong-minded citizens, however, people are not born citizens, they become citizens thanks to the education politics.

\section{References}

Dewey, J. 1944. Democracy and Education. New York: Macmillan.

— 1990. The School and Society. Chicago \& London: The University of Chigaco Press.

Dorpinghaus, A., A. Poentisch, and L. Wigger. 2013. Einführung in die Theorie der Bildung (Introdaction in Bringing Up Theory). Edited by L. Wigger and P. Vogel. 5th ed. University Dortmund.

Noddings, N. 2007. Philosopy of Education. 2nd ed. Westview Press.

Parker, W. C. and M. M. Merryfield, eds. 2002. Education for Democracy-Contexts, Curricula, Assessments. The Ohio State University.

Tsagareli, L. 2013. "Some Characteristics of Education System Between Opinion Programming and Emancipation in Modern Georgia.” Presented at the Public Discussion About the Topic-Education Policy, November 16, held by Iniciative Group, Kutaisi, Georgia. Retrieved (http://eprints. iliauni.edu.ge/usr/share/eprints3/data/1803/).

\section{Bios}

Salome Pataridze, MA in German philolology, Tbilisi State Univrsity, teacher (2011-2016), Ilia State University, Tbilisi, Georgia; research field: intercultrural researches.

Tinatin Sakhelashvili, MA in historical culturology, Tbilisi State University, Ph.D. candidate, Faculty of Humanities, Tbilisi State University, Tbilisi, Georgia, Teacher of Language and Literature at Georgian-Franch College (2004-2011), Tbilisi, Georgia; research fields: humanity and classical philology.

Tinatin Sabauri, MA in educational science, Tbilisi State University, teacher, Ilia State University, Tbilisi, Georgia; research fields: professional orientation and educational science. 